Boston University School of Law

Scholarly Commons at Boston University School of Law

Faculty Scholarship

2021

\title{
Bigotry, Civility, and Reinvigorating Civic Education: Government's Formative Task Amidst Polarization
}

Linda C. McClain

Boston University School of Law

Follow this and additional works at: https://scholarship.law.bu.edu/faculty_scholarship

Part of the Civil Rights and Discrimination Commons, Education Law Commons, and the Religion Law Commons

\section{Recommended Citation}

Linda C. McClain, Bigotry, Civility, and Reinvigorating Civic Education: Government's Formative Task Amidst Polarization, in The Impact of the Law: On Character Formation, Ethical Education, and the Communication of Values in Late Modern Pluralistic Societies 109 (Michael Welker and John Witte ed., 2021).

Available at: https://scholarship.law.bu.edu/faculty_scholarship/837

This Book Chapter is brought to you for free and open access by Scholarly Commons at Boston University School of Law. It has been accepted for inclusion in Faculty Scholarship by an authorized administrator of Scholarly Commons at Boston University School of Law. For more information, please contact lawlessa@bu.edu. 


\title{
BU School of Law
}

\section{BIGOTRY, CIVILITY, AND REINVIGORATING CIVIC EDUCATION: GOVERNMENT'S Formative TASK AMIDST POLARIZATION}

\author{
Boston University School of Law \\ Public Law \& Legal Theory Paper No. 20-9
}

March 2020

Linda C. McClain

Boston University School of Law 


\section{Bigotry, Civility, and Reinvigorating Civic Education:}

\section{Government’s Formative Task Amidst Polarization}

(forthcoming in: John Witte, Jr. et al., eds, The Role of Law in Character Formation, Moral Education, and the Communication of Values in Late Modern Pluralistic Societies (Leipzig: EVA Publishers, 2020))

Linda C. McClain, Robert Kent Professor of Law, Boston University School of Law

\section{Part One: Bigotry, Incivility, and Challenges to E Pluribus Unum}

“Calling out” bigotry and arguing over whether a public figure is or is not a bigot are visible and contentious features of daily public life in the United Sates. Charges, denials, and countercharges of bigotry seem increasingly frequent, as do claims that one is being unfairly branded a bigot. People turn to the language of bigotry in so-called culture-war issues around marriage, LGBTQ rights, and religious liberty, as well as in controversies over race, immigration, and borders. Images of climate change and the endangered "atmosphere of public life” vividly capture the worry that bigotry and a "climate of hate” damage "the protective layer of civility, which makes political discourse possible.” ${ }^{1}$ Charges of bigotry meet countercharges that political correctness is a form of bigotry or ideological intolerance. Indeed, one provocative claim is that, in the present environment, "the most pervasive form of bigotry" is political bigotry: intolerance toward people with different political opinions. ${ }^{2}$

\footnotetext{
${ }^{1}$ Robert Darnton, “Voltaire Versus Trump,” NewYork Times, Jan. 2, 2019, at A19.

${ }^{2}$ Joey Clark, “The Most Pervasive Bigotry Isn't What You Think,” Foundation for Economic Education, Aug. 22, 2017, https://fee.org/articles/the-most-pervasive-bigotry-isnt-what-you-think/.
} 
In my recent book, Who's the Bigot? Learning from Conflicts Over Marriage and Civil Rights

Law, I explore why there is so much controversy in the United States over bigotry when renouncing — and denouncing — it seems to be a shared political and constitutional value with a long history. ${ }^{3}$ On one hand, there appears to be strong bipartisan agreement that bigotry in all its forms is un-American and contrary to American ideals; on the other, there is often sharp, partisan disagreement over bigotry's forms and over who has the moral authority to call it out. During the 2016 presidential campaign, the Republican and Democratic Party platforms both denounced bigotry and various forms of intolerance, but their lists of those forms differed strikingly.

Further, the Democratic platform explicitly condemned Republican nominee, Donald Trump, for creating a "climate of bigotry.” ${ }^{4}$ During Trump’s campaign and continuing into his presidency, bipartisan warnings sounded that "bigotry seems emboldened" and "normalized." ${ }^{5}$ Civil rights groups asserted that Trump’s statements and his administration’s policies “tapped into a seam of bigotry and hate that resulted in the targeting of American Muslims and other minority groups.”6 Trump’s critics argued that such bigotry included racism, anti-Semitism, nativism, populism, xenophobia, homophobia, misogyny, and sexism. ${ }^{7}$ On the other hand, some conservative

\footnotetext{
${ }^{3}$ Linda C. McClain, Who's the Bigot? Learning from Conflicts Over Marriage and Civil Rights Law (NY: Oxford University Press, 2020).

${ }^{4}$ Republican Party Platform 2016, at 9, http://www.presidency.ucsb.edu/ws/index.php?pid'117718; Democratic Platform 2016, at 18, http://www.presidency.ucsb.edu/ws/index.php?pid'117717.

${ }^{5}$ Maegan Vazquez, "George W. Bush: Bigotry and White Supremacy Are 'Blasphemy’ Against the American Creed,” CNN, Oct. 19, 2017, https://www.cnn.com/2017/10/19/politics/bush-freedom-event/index.html (“emboldened”); Sasha Abramsky, "How Trump Has Normalized the Unspeakable,” Nation, Sept. 20, 2017, https://www.thenation.com/article/how-trump-has-normalized-the-unspeakable; Michael Gerson, "Trump Deepens the Moral Damage to the GOP,” Washington Post, Aug. 28, 2017, https://www.washingtonpost.com/opinions/trump-abuses-his-power-in-the-cause-of-bigotry/2017/08/28/1f473e3c8c22-11e7-84c0-02cc069f2c37_story.html.

6 “CAIR Report Shows 2017 On Track to Becoming One of the Worst Years Ever for Anti-Muslim Hate Crimes," Council on American Islamic Relations, July 17, 2017, https://www.cair.com/press-center/press-releases/14476-cair-report-shows-2017-on-track-to-becoming-one-of-worst -years-ever-for-anti-muslim-hate-crimes.html.

${ }^{7}$ Mythili Sampathkumar, “Trump Impeachment Vote to Happen Next Week, Congressman Promises,” The Independent, Nov. 30, 2017 (quoting Representative Al Green); Charles M. Blow, "Trump is a Racist. Period,” New York Times, Jan. 15, 2018, at A19.
} 
commentators countered that critics of Trump and his supporters are "anti-Trump bigots" and that their "political correctness" is a form of bigotry. ${ }^{8}$

The 2018 midterm elections intensified concern over polarization and brought fresh battles over bigotry. In one preelection poll, 61 percent of Democrats and those leaning Democratic would use the terms “racist/bigoted/sexist” to “describe Republicans today;” 54 percent chose “ignorant,” and 44 percent “spiteful.” Among Republicans and those leaning Republican, only 31 percent chose the terms “racist/bigoted/sexist” to “describe Democrats today,” while 49 percent chose “ignorant," and 54 percent "spiteful.”"

Commentators diagnose a new tribalism in the United States, in which the left believes that the bigotry and racism of "right-wing tribalism” is "tearing the country apart," while the right believes the "identity politics" and "political correctness" of "left-wing tribalism” are doing so. ${ }^{10}$ Americans, some argue, have growing contempt for their political opponents. ${ }^{11}$ Prominent political scientists warn of the possible death of democracy in the United States and elsewhere if core norms of “mutual toleration” erode, allowing “extremist demagogues” to go unchecked. ${ }^{12}$

\footnotetext{
${ }^{8}$ See "Sean Hannity Show," Fox News Today, Dec. 26, 2017 (guest Todd Starnes calls CNN “a dog whistle for race baiting anti-Trump bigots" and argues that those who oppose Trump are bigoted), LEXIS News Transcripts 122601cb.253; Shelby Steele, “The Soft Bigotry of Political Correctness,” Hoover Institution, April 24, 2017, https://www.hoover.org/research/soft-bigotry-political-correctness.

${ }^{9}$ Kim Hart, "Exclusive Poll: Most Democrats See Republicans as Racist, Sexist,” Axios, Nov. 12, 2018, https://www.axios.com/poll-democrats-and-republicans-hate-each-other-racist-ignorant-evil-99ae7afc-5a51-42be8ee2-3959e43ce320.html (citing Survey Monkey online poll conducted Oct. 30 to Nov. 2 among 3, 215 adults). ${ }^{10}$ David Blankenhorn, “The Top 14 Causes of Political Polarization,” The American Interest, May 26, 2016, https://www.the-american-interest.com/2018/05/16/the-top-14-causes-of-political-polarization/ (quoting Amy Chua, Political Tribes (New York: Penguin, 2018)).

${ }^{11}$ Arthur C. Brooks, Love Your Enemies: How Decent People Can Save America from the Culture of Contempt (NY: Broadside Books, 2019); see also Karen Stohr, “Our New Age of Contempt,” New York Times, Jan. 23, 2017, https://www.nytimes.com/2017/01/23/opinion/our-new-age-of-contempt.html.

${ }^{12}$ Steven Levitsky and Daniel Ziblatt, How Democracies Die (NY: Penguin, 2018), 168.
} 
Concerns over a decline in civility and tolerance—and a surge in bigotry—are not confined to the United States. Around the world, shocking incidents of lethal extremist violence motivated by hatred of religious and racial groups make condemning —and preventing—bigotry seem urgent. The role of social media on the internet in fostering hate that spills into violent action is a particular concern. It has spurred local and international demands, such as the Christchurch Call, that social media be more accountable for their content. ${ }^{13}$ In the report Pluralism in Peril:

Challenges to An American Ideal (2018), J. M. Berger explains the amplifying effect of social media. While "extremism has existed for thousands of years," takes many forms, and is "part of the human experience":

Thanks to a brave new world of instant global connectivity, the problem is perhaps more diverse than before. Extremism is a socially transmitted disease, and there are more vectors for infection than at any time in history. ${ }^{14}$

If, as Berger persuasively argues, extremism poses a stark challenge to a healthy pluralism and is the opposite of the ideal of "out of many one" (e pluribus unum), ${ }^{15}$ then what concrete measures can counter extremism? What meaning can the ideal of e pluribus unum have in this fraught and polarized environment? What concrete steps might tackle the alarming brew of hate and "otherization” that social media sites facilitate? Turning from virtual space to the shared real spaces of people’s daily interactions, what tools does government have to restore civility and to decrease contempt and prejudice (or even "political bigotry”)? What does the virtue of civility require,

\footnotetext{
${ }^{13}$ See "Christchurch Call to Eliminate Terrorist \& Extremist Content Online," christchurchcall.com; Damien Cave, “The Global Push to Make Social Media Accountable for Its Content,” New York Times, April 1, 2019, at 5.

${ }^{14}$ J.M. Berger, "Out of Many One: Defining the Opposite of Extremism," in Pluralism in Peril: Challenges to an American Ideal: Report of the Inclusive America Project (Aspen Institute, Justice Society Program, Jan. 2018), 89, 91.

${ }^{15}$ Berger, 89.
} 
and how can government inculcuate it? Is there a way forward from the bigotry-versus-politicalcorrectness divide?

\section{A Way Forward? The Civic Roles of Schools}

This chapter argues that civic education in public schools is one concrete method that government may employ to address these vexing challenges by teaching people how to coexist peacefully and cooperatively in a multiethnic and multireligious polity and to engage respectfully across difference. At a time of "heightened concern about the state of US politics and democracy,” attention has understandably turned to the role of $\mathrm{K}-12$ education in America and whether schools are "equipping students with the tools to become engaged, informed, and compassionate citizens.”16

Civic education bears on this volume's topic of the role of law in forming character, educating about ethics, and expressing values in pluralistic and polarized societies. Such education could help to reduce dangerous forms of contempt and hate. Further, one possible component of a reinvigorated civic education should be religious literacy—nonsectarian education about religion—since "religious illiteracy is often a contributing factor in fostering a climate whereby certain forms of bigotry and misrepresentation can emerge unchallenged and thus serve as one form of justification for violence and marginalization." ${ }^{17}$ Such education might help change a

\footnotetext{
${ }^{16}$ Michael Hansen, et al., "The 2018 Brown Center Report on American Education: How Well are American Students Learning?” (Brown Center on Education Policy at Brookings, June 2018), 1.

${ }^{17}$ Diane L. Moore, "High Stakes Ignorance: Religion, Education, and the Unwitting Reproduction of Bigotry," in Vincent F. Biondo III and Andrew Fiala, eds., Civility, Religious Pluralism, and Education (NY: Routledge, 2014), 112, 114.
} 
climate of bigotry and prepare students for respectful engagement and cooperation across difference in an increasingly pluralistic constitutional democracy.

As James Fleming and I argue elsewhere, “[e]ducation of children is one of government’s most significant formative responsibilities." ${ }^{\circledR 18}$ We defend an account of constitutional liberalism in which government has a responsibility to carry out a formative project of fostering deliberative democracy (political self-government) and deliberative autonomy (personal self-government). In the US constitutional and political order, schools (ideally) prepare children not only for "success in life" (to quote Brown v. Board of Education), but also provide "education for democracy"they inculcate core political values and equip children with the knowledge, skills, and habits (or dispositions) for responsible and meaningful participation in civic life.

A few examples of those prerequisites for participation are the capacity for critical thinking and reflection and for empathy and reciprocity (allowing for perspective-taking). ${ }^{19}$ "Civility" typically refers to skills that citizens need to interact with one another: how to be "responsive to one’s fellow citizens," "to question, to answer, and to deliberate with civility," and "to build coalitions and to manage conflict in a fair, peaceful manner." ${ }^{20}$ An important caveat: calling out bigotry is not necessarily uncivil or antithetical to civility. During the civil rights movement, critics of civil rights activists who challenged white supremacy and an unjust status quo accused

\footnotetext{
${ }^{18}$ James E. Fleming and Linda C. McClain, Ordered Liberty: Rights, Responsibilities, and Virtues (Cambridge, MA: Harvard University Press, 2013), 118. I have also advanced a liberal feminist account of the dual authority of families and schools to educate children and foster civic virtue. See Linda C. McClain, The Place of Families: Fostering Capacity, Equality, and Responsibility (Cambridge, MA: Harvard University Press, 2006), 50-84.

${ }^{19}$ McClain, Place of Families, 68-73.

${ }^{20}$ Campaign to Promote Civic Education, The Role of Civil Education: An Education Policy Task Force Position Paper with Policy Recommendations (Sept. 1998), 4.
} 
them of incivility. ${ }^{21}$ Those who call out bigotry today might argue that, far from being uncivil, they seek to vindicate civic ideals by demanding that the polity and its political leaders live up to them.

The term "civic education" typically refers to the task of preparing youth for responsible citizenship and is, proponents argue, "essential to the preservation and improvements of American constitutional democracy."22 Because the literature on civic education typically uses the rhetoric of "responsible citizenship" or of developing "competent and responsible citizens,"23 I use these terms here, while acknowledging that aims of civic education also apply to persons within US borders who are not citizens but are members of communities and participants in local and national politics.

\section{The Civic Role of Schools and Challenges in Carrying Out Such Roles}

Civic education faces challenge in the current political climate in the United States. How do schools carry out their civic role in times of "democratic discord," in "an increasingly polarized and partisan political climate”? ${ }^{24}$ As education scholars Meira Levinson and Jacob Fay explain, in Democratic Discord in Schools: Cases and Commentaries in Educational Ethics: "It should not be at all surprising that democratic discord finds its way into schools, since ... schools 'are, and ought to be, political sites.” Schools are political in "complicated ways": they "function

\footnotetext{
${ }^{21}$ Randall Kennedy, “State of the Debate: The Case Against 'Civility,”' American Prospect, Dec. 19, 2001, https://prospect.org/culture/state-debate-case-civility/.

${ }^{22}$ Fleming and McClain, Ordered Liberty, 118 (quoting Center for Civic Education, National Standards for Civics and Government [1994], Introduction).

${ }^{23}$ Fleming and McClain, 119 (sources omitted).

${ }^{24}$ See Jacob Fay and Meira Levinson, "Schools of, by, and for the People: Both Impossible and Necessary," in Meira Levinson and Jacob Fay, eds., Democratic Discord in Schools: Cases and Commentaries in Educational Ethics (Cambridge, MA: Harvard Education Press, 2019), 3.
} 
simultaneously as institutions in a democracy and as institutions that prepare students for democracy." 25

Levinson and Fay identify three "distinct civic roles" that schools play in educating both in and for democracy. Their account provides a helpful foundation for appreciating the connection between law and civic education and for considering what form a "reboot," or reinvigoration, of civic education might take to meet current challenges. First, "public schools have responsibilities in democracies as legal agents of the state, responsible for implementing democratically enacted public policies and laws." ${ }^{26}$ For example, many states have laws requiring schools to adopt bullying-prevention policies. Such policies impose responsibilities and duties on teachers and administrators, such as "protecting students from cyberbullying and inappropriate digital content.”27 Such laws may also require the development of an appropriate bullying-prevention curriculum, which shapes what teachers teach in schools. ${ }^{28}$

A second civic role is that "schools exist in democracies as objects of adults' and students' ongoing democratic expression and engagement.” For example, students may engage in "walkouts and other forms of protest to transform their schools ... into objects of democratic expression." ${ }^{29}$ More than fifty years ago, the US Supreme Court, in Tinker v. Des Moines Independent School District (1969), declared that neither students nor teachers "shed their

\footnotetext{
${ }^{25}$ Levinson and Fay, 4.

${ }^{26}$ Meira Levinson and Jacob Fay, “Educating for Civic Renewal,” in Levinson and Fay, Democratic Discord, 272.

${ }^{27}$ Ibid., 273.

${ }^{28}$ For example, after the Massachusetts legislature passed the Bullying Prevention and Intervention Law (2010), school officials developed guides for how to integrate bullying prevention into the curriculum. See Dr. Carol R. Johnson (Superintendent, Boston Public Schools), "Embedding Bullying Prevention in Core Curriculum: A Teacher's Guide K-12” (Focus on Children, Boston Public Schools).

${ }^{29}$ Levinson and Fay, "Educating for Civic Renewal," 273 (emphasis in original).
} 
constitutional rights to freedom of speech and expression at the schoolhouse gate”; the court upheld students’ right to wear armbands in silent protest of the Vietnam War. The high-water mark of protecting students' First Amendment rights in school, Tinker illustrates the place of schools as sites of democratic expression, with an important proviso: such expression must not impinge on the rights of other students or "substantially interfere" with the operation of the school. $^{30}$

A third civic role of school is that "schools are sites of civic preparation for future democratic citizens.” ${ }^{31}$ Undertaking civic education, I argue, is one form of such civic preparation.

Levinson and Fay caution that "in times of partisan contestation and civic upheaval,” it is challenging for schools to fulfill "any one of the roles.” Challenges multiply when "the roles themselves come into conflict”-for example, when “young people’s civic vision and activism clash with school and district policies.” 32

This chapter considers some of the challenges of carrying out civic education in the present political climate. I begin with a brief articulation of civic education as one way that law shapes character. I introduce the "why" and the "what" of civic education, that is, its aims and content. The chapter also addresses the "how," that is, how to carry out civic education.

The Why, What, and How of Civic Education-and Civic Gaps

\footnotetext{
${ }^{30} 393$ U.S. 503, 506, 508-09 (1969).

${ }^{31}$ Levinson and Fay, "Educating for Civic Renewal,” 273.

32 Ibid.
} 
As to the "why" and "how" of civic education, consider the admonition of Benjamin Rush, signer of the Declaration of Independence. He asserted that the legislature must play an indispensable role in aiding with the "one method" of "rendering a republican form of government durable”: "disseminating the seeds of virtue and knowledge through every part of the state, by means of proper places and modes of education.” ${ }^{33}$ Such a premise is part of a long history of admonitions that inculcating seedbeds of virtue-or seedbeds of civic virtue-is necessary to sustain the American experiment in constitutional democracy. As expressed by former US Supreme Court Justice Sandra Day O’Connor (a strong proponent of civic education), another premise is that "the practice of democracy" must be "taught and learned anew by each generation of citizens." 34 This chapter focuses on the role of government-in the form of schools - to do such teaching, but readers should bear in mind that another important (although not unproblematic) premise about civic virtue is that the family, religious institutions, and other parts of civil society are also important seedbeds of such virtue. ${ }^{35}$

Conversations within the United States and in Europe suggest notable parallels with respect to challenges concerning the what and how of civic education. As Per Mouritsen and Astrid Jeager explain, introducing a survey of civic education in several European countries: “At its heart, civic education is designed to produce 'good citizens' — though ideas about what constitutes such an individual vary from country to country.” 36 Within the United States, that idea varies state-to-

\footnotetext{
33 Peter Levine and Kei Kawashima-Ginsberg, "The Republic Is (Still) at Risk—and Civics is Part of the Solution” (Briefing Paper for the Democracy at a Crossroads National Summit, Sept. 21, 2017), 19, quoting Rush.

34 Ibid., 19.

${ }^{35}$ See McClain, Place of Families, 50-84 (critiquing inattention to problems of sex inequality in the family in accounts of families as seedbeds of civic virtue); Fleming and McClain, Ordered Liberty, 81-111 (critically evaluating calls for renewal of civil society).

${ }^{36}$ Per Mouritsen with Astrid Jaeger, Designing Civic Education for Diverse Societies: Models, Tradeoffs, and Outcomes (Integration Futures Working Group, Migration Policy Institute Europe, Feb. 2018), 1. The report
} 
state (and even within states), as do specifics about how best to inculcate that idea and how much to invest in doing so.

This regional diversity might seem surprising, since robust civic education is a perennial concern of various national commissions and summits. The title of a report from one such summit captures this concern: “The Republic is (Still) at Risk—and Civics is Part of the Solution.”37 Civic education, however, has not been part of federal testing mandates, such as the bipartisan No Child Left Behind Act of 2002, or the more recent Common Core State Standards Initiative, launched by a bipartisan group of governors and focused on mathematics and "English language arts and literacy."38

In the United States, “all 50 states have standards for social studies, which is a broad category that includes civics, American government, American history, and other subjects considered especially relevant to learning to be an effective and responsible citizens.”39 States vary considerably, however, on how much civics they teach and how they teach it. ${ }^{40}$ One national measure of young people’s civic knowledge is discouraging: only 23 percent of eighth graders taking the National Assessment of Education Progress (NAEP) civics exam performed at or above the proficient level, and “achievement levels have virtually stagnated since 1998." 41 Also

\footnotetext{
"examines the diversity of national models that have emerged in Europe, focusing on Denmark, France, Germany, Sweden, and the United Kingdom”: Mouritsen and Jaeger, 3.

${ }^{37}$ Levine and Kawashima-Ginsberg, "The Republic Is (Still) at Risk."

${ }^{38}$ Dana Goldstein, “Common Core After 10 Years: Pass? Or Fail?,” New York Times, Dec. 7, 2019, at A1. The Common Core standards concern (1) English language arts/literacy and (2) mathematics. See Common Core State Standards Initiative, http://www.corestandards.org/.

${ }^{39}$ Levine and Kawashima-Ginsberg, "The Republic Is (Still) at Risk," 17.

${ }^{40}$ Sarah Shapiro and Catherine Brown, "The State of Civics Education," Center for American Progress, Feb. 21, 2018, https://www.americanprogress.org/issues/education-k-12/reports/2018/02/21/446857/state-civics-education/. ${ }^{41}$ Ibid., 1.
} 
troubling is that there are "profound disparities in civic knowledge and participation” among young people: those “flat and low results” mask "substantial gaps” in scores, with more affluent children and children with college-educated parents "more than five times more likely to score 'proficient'” on the NAEP than those eighth graders who qualified for free or reduced-price lunch and whose parents lacked a high school diploma. ${ }^{42}$

\section{Contours of an Improved Model_or Reboot—of Civic Education}

The current environment, including the displacement by social media of print newspapers and the ever-growing diversity of the US population, requires new thinking about effective forms of civic education. If, as educators propose, civic education "must be different in the 21st century" ${ }^{43}$ to be effective, then what form should that reboot take? In the confines of this chapter, I can offer only a sketch.

A helpful starting place is the briefing paper "The Republic Is (Still) at Risk—and Civics is Part of the Solution,” written by Peter Levine and Kei Kawashima-Ginsberg for the Democracy at a Crossroads National Summit, held in 2017. This report begins with the problem of Americans’ loss of trust in each other, in whether their fellow citizens are capable of governing the republic, and in political institutions. The problem of polarization, the report observes, is not simply one of political disagreement, but that an "increasing proportion of Americans 'dislike, even loathe' people of a different political party of their own.” Young people are coming of age as citizens in

\footnotetext{
${ }^{42}$ Levine and Kawashima-Ginsberg, "The Republic is (Still) at Risk,” 7.
}

${ }^{43}$ Ibid., 10. 
a "caustic environment," which may be an explanatory factor in low youth turnout in elections and declining faith in democracy as a form of government. ${ }^{44}$

“Civic learning," properly carried out by schools, is “an essential part of the solution” to this caustic environment, the briefing paper contends, and the "best vehicle" for training young people to "sustain our democracy":

In a society characterized by weak civic institutions, balkanized public discourse, and profoundly unequal civic engagement, schools can offer all young people opportunities to learn fundamental facts and skills, engage with each other and with their communities, and develop dispositions and values supportive of a republican form of government. ${ }^{45}$

Civic education matters both for the individual and for society: individuals lacking "the levels of skills, literacy, and training essential" to the new era will be "effectively disenfranchised"; further, a high level of "shared education" is critical for "a free, democratic society and to the fostering of a common culture, especially in a country that prides itself on pluralism and individual freedom.” Moreover, as noted earlier, the decline in associational life in the United States is "felt unequally": low-income youth are "widely disconnected from civic life," and “30\% of urban and suburban residents see themselves living in civic desserts.” Thus, civic education must acknowledge and address inequalities (economic and race-based) both in opportunities for civic engagement and in learning outcomes about civics. ${ }^{46}$

\footnotetext{
${ }^{44}$ Ibid., $1-3$.

${ }^{45}$ Ibid., 3.

${ }^{46}$ Ibid., 3, 8-9. Recognizing these issues, one recent report calls for a model of civics that attends to the "interests, identities, and life experiences of young people of color.” Cathy Cohen, Joseph Kahne, and Jessica Marshall, “Let’s
} 
What "works” in civic education? Fortunately, the briefing paper reports, there is useful knowledge from the field of civic learning about "promising practices”—or "proven practices”that are "effective when done well.” The report describes six such practices: (1) courses on civics, government, law, and related topics; (2) deliberations about current, controversial issues; (3) service-learning; (4) student-led voluntary associations; (5) student voice in schools; and (6) simulations of adult civic roles. Some of these practices occur within the classroom. For example, with respect to the second practice, deliberation: "a large body of research finds that facilitated, planned discussions teach deliberative skills and increase students’ knowledge and interest.” Teaching such skills and habits would be a valuable corrective: "perhaps the most evident deficit in American civic life today is the lack of discussion across political and social differences. ${ }^{47}$

Other proven practices might take place inside and outside of the classroom, such as simulations of adult civic roles. Traditional simulations include mock trials and Model UN programs; newer forms include the widely used iCivics learning program, which engages students in online roleplaying games to "simulate how government works" and to participate in processes like national elections. $^{48}$

Go There: Making a Case for Race, Ethnicity and a Lived Civics Approach to Civics Education” (GenForward at the University of Chicago, Chicago, Illinois, 2018), available at https://www.civicsurvey.org/publications/292.

${ }^{47}$ Levine and Kawashima-Ginsberg, 4.

${ }^{48}$ Ibid. 
Some proven practices take place outside of the classroom, such as student-led voluntary associations, in which students learn Alexis de Tocqueville’s famous "arts and sciences of association.” Levine and Kawashima-Ginberg explain that when such groups work on "shared projects over time,” members develop "habits of participation that persist for decades.” Fostering "student voice in schools" so that students feel that they are influencing the "climate and policies of their schools” and that their voices are "respected and valued,” helps young people develop into "more effective, skilled, and knowledgeable citizens.” Finally, service-learning combines inclass and out-of-class experience, as students engage in community service as well as "academic study of the issues addressed by the students' service,” where students might discuss "underlying causes of social problems.” Positive outcomes from such service-learning include habits and values of engagement. ${ }^{49}$

The briefing paper recommends these proven practices. It offers examples of a few states successfully passing and implementing legislation that makes civics a priority and incorporates some of the practices. ${ }^{50}$ It also calls for innovation because "civics must be different in the 21st century" to meet challenges of polarization, growing diversity, and growing inequality. It must, in the words of the report:

- Prepare students for a world of social media instead of printed local newspapers.

- Equip them to navigate a polarized society that faces complex and environmental challenges.

${ }^{49}$ Ibid.

${ }^{50}$ Ibid., 12-16. 
- Engage a generation that is far more diverse in terms of race, religion, ethnicity, national origin, and economic circumstances than any since World War II [and recognize that] [t]his rich diversity of cultural backgrounds is an asset that requires responsive teaching.

- Empower all students for effective civic engagement, countering the unequal resources and opportunities in their schools and communities.

- $\quad$ Start early and be a priority from grades $\mathrm{K}$ to $12 .^{51}$

The first item on the list, teaching students "news media literacy education,” seems an obvious component of effective twenty-first-century civic education, as people turn to social media instead of printed local newspapers for information. This turn brings benefits and costs. As social media platforms "give access to an enormous variety of sources and perspectives," young people “are increasingly empowered to influence the topics and stories that are widely shared.” On the other hand, they are “deluged with unreliable information and actual propaganda, and research shows that most young people perform poorly at distinguishing fake news from reliable news.” The briefing paper expresses confidence that schools can teach young people such discernment skills and to be "effective producers of news." ${ }^{2}$ Such media literacy seems crucial after the 2016 US presidential election drew attention to “the susceptibility of American voters' beliefs to false or misleading information.”53

Some Challenges about “Engaging” Diverse Students and Teaching Controversies

\footnotetext{
51 Ibid., 10.

52 Ibid., 5.

${ }^{53}$ Hansen, et al., "Brown Center Report,” 1.
} 
“The Republic Is (Still) at Risk” proposes a new practice of engaging a more diverse generation of students, but does not explicitly discuss how civic education could engage students who identify as LGBTQ. Doing so is important since, surveys find, such students are significantly more likely than their heterosexual or cisgender peers to experience bullying, harassment, or negative self-image, and to miss school because they feel unsafe or experience discrimination based on their sexual orientation or gender expression. ${ }^{54}$ A Human Rights Campaign survey found that "only 13\% of LGBTQ youth report hearing positive messages about being LGBTQ in school,” and some students hear about the LGBTQ community only in the context of conversations about HIV/AIDS. ${ }^{55}$ These images can have a powerful impact on students' feelings of self-worth. As Sarah Schmidt observes, in "Queering Social Studies: The Role of Social Studies in Normalizing Citizens and Sexuality in the Common Good": "Gay must be bad if the only images and discussions we can find are negative." ${ }^{56}$ When students are unable to see positive reflections of themselves in school materials, they will have difficulty seeing their worth in other areas of their lives.

In writing about the role of schools in fostering resilience in LGBTQ youth, legal scholar Martha Albertson Fineman contends that “[m]ost schools ... do not effectively educate around concepts and practices of what used to be called 'civic virtue'—-the idea that diversity, civility, tolerance, compromise, and commitment to nonviolent dispute resolution are essential life-skills in a

\footnotetext{
${ }^{54}$ I use the term "cisgender" here to refer to a person whose sense of gender corresponds to the sex identified to them at birth, e.g., male or female. For recent surveys, see Joseph G. Kosciw, et al., The 2017 National School Climate Survey: The Experiences of Lesbian, Gay, Bisexual, Transgender, and Queer Youth in Our Nation's Schools (NY: GLSEN, 2018); Human Rights Campaign (HRC), 2018 LGBTQ Youth Report (2018).

${ }^{55}$ HRC, 2018 LGBTQ Youth Report, 8.

${ }^{56}$ Sandra J. Schmidt, "Queering Social Studies: The Role of Social Studies in Normalizing Citizens and Sexuality in the Common Good,” Theory \& Research in Social Education 38/3 (Summer 2010): 314.
} 
diverse democracy." ${ }^{57}$ If students are not taught these skills in school, and are not given the opportunity to practice them with their peers, the consequences can be negative and immense, particularly for LGBTQ students. By comparison, when civic education focuses on teaching tolerance and explicitly teaches about LGBTQ issues, it can be extremely beneficial for students who identify as LGBTQ and have a positive impact on their feelings of safety in school and their likelihood to attend school. ${ }^{58}$ Similar positive effects can follow when staff members are supportive of LGBTQ students and of in-school clubs and organizations, such as gay-straight alliances (GSAs). ${ }^{59}$ Schmidt argues that civic education should "explore the discourse of sexuality and citizenship” to understand how LGBTQ issues are "part of the common good.” Students should be taught to think critically about the common good so that the concept includes “advanc[ing] equality and justice for all,” rather than simply reifying the status quo. ${ }^{60}$

Teaching students to think critically and to deliberate respectfully across difference is no easy task, as the case studies and commentaries presented by Levinson and Fay in Democratic Discord in Schools make vividly clear. Educators may share a commitment to "teaching the controversies,” or helping students learn how to research and critically evaluate and discuss controversial issues, but may disagree over whether certain matters should be subject to debate. For example, in one study presented in the volume, Northern High School uses a tenth-grade social studies curriculum, "Power of Persuasion” (PoP), to challenge students "to research and critically evaluate a controversial issue, take a position, and present their arguments to

\footnotetext{
${ }^{57}$ Martha Albertson Fineman, "Vulnerability, Resilience, and LGBT Youth,” Temp. Pol. \& Civ. Rts. L. Rev. 23 (2014): 307, 323-24.

${ }^{58}$ GLSEN, 2017 National School Climate Survey, 56.

${ }^{59}$ Ibid., 109-10.

${ }^{60}$ Schmidt, “Queering Social Studies,” 319.
} 
classmates.” After the class presentation, each social studies class selects the strongest pro and con position papers for a schoolwide "Pop-Off” during the morning assembly. Before the assembly, students complete "an anonymous poll about where they stood on the issue," and then the winning representatives from each class have 90 seconds to present their "Pop-Talk to convince their peers about the desirability of their position.” At the conclusion, another poll is taken, and the declared winner, or "PoP-Off Powerhouse," for that topic is whichever team converted the largest number of people to its position.

This was a popular program, but much depended on “teachers' selecting the right controversial issue to focus on each time.” ${ }^{61}$ For example, sharp disagreement arose among the teachers when one teacher, Jack, hesitantly proposed the topic of “the debate about transgender students' access to bathrooms," since it was "big in the news right now.” Jack's hesitation stemmed from a concern over whether "we should be treating transgender bathroom rights as a controversial question.” Even though Jack recognized that it was being debated in various statehouses as controversial, he asked: "How can we treat gender discrimination as something that is controversial, not just wrong?” Other teachers expressed surprise that Jack, who normally did not shy away from discussing controversial issues, would advocate taking this issue off the table. They countered that they must prepare students to be "informed and engaged citizens" and to think about the questions critically, especially since the school had already received "two different sets of federal guidelines about who should use which bathroom.” Some teachers argued that, while caution is needed, given the present “polarized and partisan” political debate, it was important to facilitate the conversation among students. Jack countered that while

\footnotetext{
${ }^{61}$ See Ellis Reid, Heather Johnson, and Meira Levinson, "Politics, Partisanship, and Pedagogy: What Should be Controversial in K-12 Classrooms," in Levinson and Fay, Democratic Discord in Schools, at 177-78.
} 
“inquiry, critical thinking, and persuasive writing and speaking are incredibly important," he did not think that "debating what are effectively human rights questions is ethically responsible," since the school should be upholding "basic democratic principles like tolerance, equality, and human rights." Indeed, he did not think that "as a school we should be encouraging students to treat this as having multiple reasonable perspectives.” Colleagues expressed concern about teachers taking sides or engaging in “censorship of mainstream political issues;” they stressed the need to create a safe space for students to discuss the arguments and counterarguments they would need when discussing the issue in the world. The case study ends without resolution, as one of the teachers asks, "How should we be preparing our students for democratic citizenship in what feels like an increasingly uncivil world?” ${ }^{2}$ The several commentaries on this case study address this and other questions as they point out the numerous challenges educators face in engaging students in encountering and understanding different perspectives on controversial issues, but also in creating the conditions so that students may do so in a safe and respectful environment. ${ }^{63}$

\section{Religious Literacy as a Component of Civic Education}

One promising feature of a twenty-first-century reinvigorated civic education not mentioned in “The Republic (Still) at Risk,” but one that arguably could foster civility and combat bigotry, is religious literacy—nonsectarian education about religion. I will briefly sketch the case for including religious literacy as among the best practices for effective civic education.

\footnotetext{
62 Ibid., 179-81.

${ }^{63}$ See, e.g., Neema Avashia, "Moving Beyond the Echo Chamber," in Levinson and Fay, Democratic Discord in Schools, at 183-86.
} 
The basic case for religious literacy is well put by Diane L. Moore, founding director of the Religious Literacy Project at Harvard Divinity School. In her essay “High Stakes Ignorance: Religion, Education, and the Unwitting Reproduction of Bigotry,” Moore argues:

First, there exists a widespread illiteracy about religion that spans the globe; second, one of the most troubling and urgent consequences of this illiteracy is that it often fuels prejudice and antagonism, thereby hindering efforts aimed at promoting respect for pluralism, peaceful coexistence, and cooperative endeavors in local, national, and global arenas; and third, it is possible to diminish religious illiteracy by teaching about religion from a nonsectarian perspective in primary, middle, and secondary schools. ${ }^{64}$

The report Pluralism in Peril similarly diagnoses a widespread and dangerous religious illiteracy and recommends that "teaching about religion and engaging youth in religious literacy programs in public and private schools and youth service organizations can diminish that illiteracy and the prejudice that attends it, so long as it is done using the non-devotional, academic perspective called religious studies.”65

Both of these arguments for teaching religious literacy in public schools draw on 2010 guidelines offered by an American Academy of Religion (AAR) task force on religion in the public schools, chaired by Moore. The guidelines cautioned that "illiteracy regarding religion is widespread” and that the "prejudice and antagonism" such illiteracy fueled was a great threat to the United

\footnotetext{
${ }^{64}$ Moore, "High Stakes Ignorance,” 112

${ }^{65}$ Allison K. Ralph and Seán Rose, "Religious Literacy and Inclusion in Education Settings and Youth-Serving Organizations: Opportunities to Grow the Field,” in Pluralism in Peril, 17, 18.
} 
States. ${ }^{66}$ The guidelines explained how $\mathrm{K}-12$ public schools could teach about religion in a constitutional manner. ${ }^{67}$

Moore argues that while "[l]earning about religion is no guarantee that religious bigotry and chauvinism will cease," it "will make it more difficult for such bigotry and chauvinism to be unwittingly reproduced and promoted.”68 Effective education about religions and religious pluralism will, she contends, increase understanding of different religions and make it likely that students will be more conscious and less judgmental of the religious values of their peers.

Readers may ask: why schools, rather than parents and religious communities? After all, the First Amendment prohibits government establishment of religion and protects the free exercise of religion, and under the Fourteenth Amendment, parents have a fundamental liberty concerning the care, control, and education of their children. Moore argues that schools have a proper role and responsibility to provide nonsectarian education about religion, which has the pedagogical purpose of creating a more tolerant and stable society. ${ }^{69}$ "Religious illiteracy has moral and civic consequences that are often dire., ${ }^{70}$ Thus, it is vital to teach about religion in a way that is responsible, conscientious, and clearly aligned with other educational values in order to increase tolerance and combat bigotry in society. Educators therefore "need to be clear" about why teaching about religion is "a valid and, indeed, important focus for inquiry in relation to the broader educational goals that a given teacher, school, district, or nation affirms and intentionally

\footnotetext{
${ }^{66}$ American Academy of Religion, "Guidelines for Teaching about Religion in K-12 Public Schools in the United States” (April, 2010), 4-7.

${ }^{67}$ AAR, "Guidelines," 7-9.

${ }^{68}$ Moore, "High Stakes Ignorance,” 115.

${ }^{69}$ Ibid., 116.

${ }^{70}$ Ibid., 125.
} 
tries to promote."71 Such clarity not only will help students better learn about religion by aligning it with other educational values, but also will allay parental fears about religious education in schools.

Moore describes two different types of parental fears that will be familiar to anyone who has studied controversies between parents and schools over curriculum. On one hand, "[c]onservative religious practitioners from many faith traditions often oppose learning about religion in schools for they feel that it is the role of faith communities and families to teach about religion from their own theological perspectives.” Thus, "learning about religion from an academic lens presumes the legitimacy of multiple religious worldviews, which is theologically problematic in some circles." On the other hand, areligious parents are likely to "fear that if religion is introduced in the schools some teachers will inevitably proselytize either by intention or default due to a lack of adequate training and clear understanding of the distinction between an academic and devotional approach." ${ }^{72}$ While religious parents may fear that their children will begin to question their faith in relation to other, purportedly equally legitimate religions, areligious parents may worry that religious education in schools will bring their children into a specific religion.

To quell fears on both sides, Moore argues, it is important that there be "a difference between religion understood through the lens of personal devotional practice and the academic study of religion."73 Parents and students alike must understand that the academic purpose of religious

\footnotetext{
${ }^{71}$ Ibid., 120.

${ }^{72}$ Ibid., 115-16.

${ }^{73}$ Ibid., 113.
} 
education is to increase understanding of different perspectives, rather than force any particular perspective onto students. "Training in religious literacy,” Moore argues, "provides citizens with the tools to better understand religion as a complex and sophisticated social/cultural phenomenon and individual religious traditions themselves as internally diverse and constantly evolving as opposed to uniform, absolute, and ahistorical.” In contrast to the way that religion is currently taught, Moore argues that students must learn to see the nuance in religion and learn about the historical contexts in which religions formed and evolved, so that they can better understand religion as something that is living and changing rather than fixed. ${ }^{74}$

Many public school teachers, however, do not have the training needed to effectively teach religious education to a diverse population of students. Thus, it is necessary "to give teachers the training they need to do so more responsibly than they are often currently able to do.”75 Encouragingly, there are a number of resources for doing so in addition to the AAR guidelines. For example, after a pilot study in Hartford, Connecticut, Moore’s Religious Literacy Project has developed a "continuing-education program" for teachers with "webinars, in-person seminars, and hybrid online/in-person opportunities."76

In Pluralism and Peril, contributors Allison K. Ralph and Seán Rose argue that teaching students to "engage intentionally with religious pluralism and diversity" can help to "build strong and resilient communities and a functioning democratic process.” They further argue that, in addition to public schools, a vital resource for such engagement is youth-serving organizations (such as

\footnotetext{
${ }^{74}$ Ibid., 115.

${ }^{75}$ Ibid., 116.

${ }^{76}$ Ralph and Rose, “Religious Literacy and Inclusion,” 20-24. For more examples, see The Religious Literacy Project, https://rlp.hds.harvard.edu/.
} 
Boys and Girls Clubs of America, the YMCA, and others), which "have almost unparalleled reach in diverse communities throughout the United States."77

To be sure, teaching religious literacy in public schools presents various challenges, of which addressing competing types of parental objections is but one example. ${ }^{78}$ One common and important premise that justifies such education, however, is that "what most undermines a pluralistic society is ignorance - both an ignorance of civic knowledge and an ignorance of religious knowledge."79 Such education might help change such a climate and prepare students for respectful engagement and cooperation across difference in an increasingly pluralistic constitutional democracy.

\section{Grounds for Optimism?}

Let us assume, then, that a "high-quality civics education" would combine the six proven practices with some of the additional ones recommended in the briefing paper "The Republic Is (Still) at Risk,” such as media literacy. ${ }^{80}$ How well are states doing if measured against that checklist? One recent fifty-state inventory that added media literacy found that "some—-but certainly not all—[proven practices] are widespread throughout the country.” The briefing paper concludes by offering some "grounds for optimism," based on such indicators as more young people interested in iCivics games and more states considering strengthening their civic-learning

\footnotetext{
${ }^{77}$ Ralph and Rose, 18, 24.

${ }^{78}$ For examples, see the contributions to Biondo and Fiala, Civility, Religious Pluralism, and Education.

${ }^{79}$ Shapri LoMaglio, "Christian Commitment to Pluralism Should Not Waiver," in Pluralism in Peril, 105, 107.

${ }^{80}$ Ibid., 16-17.
} 
standards. ${ }^{81}$ Innovation and experimentation, the authors conclude, are critical to carrying forward "the American experiment in republican self-government." 82

Contemporary discourse about civic education offers considerable insight about those "proper places and modes of education” to which Benjamin Rush refers, and how legislatures may promote them. Might we hope that a renewed commitment to civic education, transformed in the ways discussed earlier, could help to bring about a healthier, less-toxic climate with a more responsible, virtuous citizenry in which calling out bigotry is less frequent and necessary?

${ }^{81}$ Levine and Kawashima-Ginsberg, "The Republic Is (Still) at Risk,” 18.

${ }^{82}$ Ibid., 18. 